The University of San Francisco

USF Scholarship: a digital repository @ Gleeson Library |

Geschke Center

Philosophy

College of Arts and Sciences

1997

\title{
The Nazi! Accusation and Current U.S. Proposals
}

Thomas A. Cavanaugh

University of San Francisco, cavanaught@usfca.edu

Follow this and additional works at: http://repository.usfca.edu/phil

Part of the Philosophy Commons

\section{Recommended Citation}

Cavanaugh, Thomas A., "The Nazi! Accusation and Current U.S. Proposals" (1997). Philosophy. Paper 29.

http://repository.usfca.edu/phil/29

This Article is brought to you for free and open access by the College of Arts and Sciences at USF Scholarship: a digital repository @ Gleeson Library | Geschke Center. It has been accepted for inclusion in Philosophy by an authorized administrator of USF Scholarship: a digital repository @ Gleeson

Library | Geschke Center. For more information, please contact repository@usfca.edu. 


\section{T.A. Cavanaugh, Philosophy, University of San Francisco \\ Penultimate draft of: The Nazi! Accusation and Current U.S. Proposals,} Bioethics, 11, Nos. 3-4, July 1997, pp. 291-297.

\section{THE NAZI! ACCUSATION AND CURRENT U.S. PROPOSALS}

In discussing the relevance of Nazi "euthanasia" to the practices of physician-assisted suicide (PAS) and voluntary active euthanasia (VAE), currently proposed for legalization in the U.S., there are at least two reasons for putting scare quotes around 'euthanasia' when referring to the Nazi practice of killing, amongst others, the mentally ill, the handicapped, epileptics, and certain children and infants. ${ }^{i}$ First, to call what contemporary advocates of physician-assisted suicide (PAS) and voluntary active euthanasia (VAE) propose Nazi! is hyperbolic. Second, it is an ad hominem, the very weakest of arguments, indeed, perhaps no argument at all. Calling people and practices names is odious and futile; for to say that PAS and VAE are or will become equivalent to what the Nazis did is not to offer reasons against either practice. Indeed, to call the German "euthanasia" program Nazi! is not to argue even against that program, for those killings were not wrong merely because Nazis did the killing. ${ }^{\text {ii }}$

Late Twentieth Century ethical discourse has relied on the Nazis to exemplify the category of the absolutely wrong with too little reflection on the 
circumstances that lead to this rhetorical strategy. Nazis serve as a convenient prop to be dusted off and pointed to by those speaking in a society permeated by emotivism, the position that ethical discourse is constituted entirely of assertions and counter-assertions of taste. Since contemporary disputants do not agree about the substantive points and first principles from which ethical reasoning begins they find it difficult to achieve closure. ${ }^{\mathrm{iii}}$ Those who rely on the Nazi! accusation assume or hope that everyone agrees that the Nazi killing practices are always and everywhere wrong. Thus, instead of being forced to sit in perpetual sackcloth and ashes, Nazis putatively function as the one point of agreement from which public ethical argument can depart confidently. This idol of the forum is wobbling precariously, however, as those who teach ethics realize. Students lack confidence that they can establish, nor is there reason to think that they have been provisioned with the resources to argue, that what the Nazis did was absolutely, transculturally, everywhere and at every time wrong. Their lack of confidence reflects one popularly accepted emotivist position: that disagreement is shrill and interminable because ethical matters do not admit of truth. Indeed, the phenomenon of the Nazi! charge reflects despair precisely in the face of the conviction that there are no ethical truths. Interlocutors are reduced to assertion and counter-assertion, one making and the other denying the accusation. The Nazi! accusation -- used in divergent ways by myriad parties -- should be understood as an ethical cri de cœur of interlocutors attempting to find that much coveted Archimedean place to stand and from which to bring shared moral convictions to bear on our public 
practical reflections.

This charge, however, should be put aside in contemporary discussions; for it eviscerates discourse of standards on both sides of the debate. Opponents of contemporary PAS and VAE would need to make the Nazi! accusation stick; proponents would need only to escape from the Nazi shadows. Neither is enough; for neither is ultimately conclusive or convincing. Just as some practice is not wrong merely because the Nazis did it or merely because it will lead to what the Nazis did do, so also, no practice is justified solely by the fact that the Nazis did not do it or because it will not lead to what they did do.

Keeping the scare quotes on 'euthanasia' in the phrase 'Nazi "euthanasia"" and putting the Nazi! accusation away, let us ask: first, what general philosophical presuppositions does Nazi "euthanasia" share with PAS and VAE as currently proposed for legalization in the U.S.? second, what made Nazi "euthanasia" unique? third, what contemporary characteristics of the U.S. would specify the philosophical presuppositions underlying PAS and VAE?

The first general presupposition common to the practices in question is the notion that there are certain lives that ought not to be lived, and, more importantly, that the fact that those lives ought not to be lived partially justifies homicide. Nazis spoke of a life being unworthy of life -lebensunwerten Lebens. ${ }^{\text {iv }}$ This way of speaking indicates that the Nazis regarded the subject, an individual human being, as not being worthy of the 
property of being alive. Contemporary advocates of PAS and VAE speak of life, under certain conditions, as not worth living. They regard the individual as having a property that is not worth having. Thus, the Nazis devalued the subject who possessed life while contemporary advocates of PAS and VAE question the value of the life possessed by the subject. In both cases the inference is made that a life that ought not to be lived ought to be ended actively.

This shared inference is itself significant. For from the position that a life ought not to be lived, it need not follow that the life ought to be ended. One might reasonably hold that some life ought not to be lived while not holding that if such a life were being lived it ought to be ended. For example, a mother of children whose lives are chronically punctuated by suffering might reasonably choose not to have another child because she judges the life it would have as a life that ought not to exist. Yet, she need not thereby be committed to killing her children who are leading such lives. Thus, it is significant that both the Nazis and contemporary proponents of PAS and VAE assume that from the fact that a life ought not to exist, it follows that such a life ought to be ended actively.

Nazi "euthanasia" and the practices of PAS and VAE offer homicide as an answer to the question: what does one do with a life that ought not to exist? This reveals another presupposition common to these positions. Namely, that life itself cannot be trusted with life; that the body does not have its own reasons of which reason is sometimes not aware. This judgment that 
the lives that ought not to be lived cannot be entrusted to nature nevertheless relies on certain idealized views of nature in terms of which precisely which lives those are can be discerned. That is, the lives that ought not to be lived are determined in biological terms vis-à-vis ideals of health and human flourishing.

The Nazi biological ideal was racist, the purity of the Aryan Volk. ${ }^{\mathrm{v}}$ The Aryan race was all too human for the Nazis, as evidenced by what they could regard only as its unsightly embarrassments to be gotten rid of: children with hydrocephaly, microcephaly, or Down's syndrome; adults with withered legs, senility, or epilepsy. Thus, the Nazis made the judgment that a life was not worth living in terms of and on behalf of a racist idealization of a biologically purified Aryan Volk.

Contemporary proponents of PAS and VAE make the judgment that a life is not worth living in terms of the physical qualities of that life. ${ }^{\mathrm{vi}}$ This is a labile concept; nonetheless, amongst the proponents of PAS and VAE, there is a consensus that certain conditions render life not worth living: a terminal illness with intractable physical pain or a chronic progressively debilitating disease. ${ }^{\text {vii }}$ Thus, although they agree that the criteria grounding the judgment that a life ought not to exist are generally biological, Nazis and contemporary advocates of PAS and VAE base this judgment on different biological standards.

More importantly, although Nazis and contemporary advocates in principle agree that there are lives that ought not to be lived, the two groups 
offer distinct loci for giving this judgment authority. Contemporary advocates hold that while all of us can make the judgment that a life is not worth living, only the one living that life makes the judgment authoritatively. Thus, contemporary advocates hope to insure that of those lives that are not worth living -- for example, a life with an incurable progressively debilitating disease -- only those judged to be not worth living by the one living the life will be taken. ${ }^{\text {viii }}$

Nazis, on the other hand, were indifferent to whether or not the individual or surrogate agreed with them that the life ought to be ended. It is true that Hitler -- always the opportunist -- did begin the killing by responding to the Knauer family's request that a handicapped infant be killed, ${ }^{\text {ix }}$ and the Nazis did kill some children whose parents wanted them to be killed and some adults whose spouses or children wanted them to be killed. ${ }^{\mathrm{x}}$ These killings, however, were merely the inevitable coincidental agreements between state and family that occur when upwards of seventy thousand people are killed. ${ }^{\mathrm{xi}}$ Turning to the contemporary U.S., a number of factors will further specify the general philosophical presuppositions grounding PAS and VAE. The first concern the practical and public dynamics of the logic underlying PAS and VAE. Most advocates of PAS and VAE want to keep the two primary criteria of the justification together -- that the death be voluntary and brought about for a good reason. These criteria, however, exist in tension with one another -- as is evidenced by those soft paternalists who think that really wanting to die is itself a sufficiently good reason for PAS or VAE. ${ }^{\text {xii }}$ 
Moreover, these criteria face the perhaps peculiarly American dynamic by which the legal develops from what people may do into what people do to become what people ought to do. In the States, the legally permissible becomes the norm which in turn becomes the socially obligatory. As patients with terminal progressively debilitating diseases choose to kill themselves or to be killed they establish a social norm. However, once this becomes the social norm the burden of justification shifts to those who depart from it. As the conviction takes publicly that others significantly like them were correctly killed because they had a good reason to be killed and acknowledging this asked to be assisted or to be killed, so also to that very extent the conviction develops that some are not being reasonable in not wanting death. If the law accepts these practices, it thereby undermines the autonomy of those who have the same reasons to be killed but do not apprehend them as being good reasons for being killed. Of course, some will find this description true to their own experience of social norms and pressures while others will find it unduly speculative. There is, however, another more practical exigency that will particularize these practices in the States, namely, the phenomenon of capitation.

Advocates of PAS and VAE tend to romanticize the compassionate killing of those who want to be killed without sufficient reflection on the way in which health care has come to be delivered and will continue to be delivered in the States. ${ }^{\text {xiii }}$ In a fee-for-service environment, a physician is paid for the services she provides to her patients. Thus, she is tempted to do more 
in order to make more. In a capitated system, however, a physician is paid more the less she does. Thus, her temptation changes from doing more to doing less in order to make more. This is not to argue against capitation as a means by which to control health care costs. Nonetheless, when introducing PAS and VAE into a context in which capitation is becoming the standard and health care costs are thought to be out of control, one must realize that significant savings are to be had in convincing those who have become expensive in terms of health care that death is one option for them. Significant amounts of money could be made by killing the sickest patients, especially those terminally ill who have no prospect of returning to work or to conditions of health in which they would make net financial contributions to health care costs. Once law legitimates killing those who judge their lives to be not worth living, it legitimates making and saving money by killing those people. In order to convince these individuals and their physicians, why not advertise, promote or incentivize death as the therapy of choice? One would be innocent of any knowledge of human motivation if one thought that the desire for gain were not a significant and largely ungovernable factor facing the legalization of PAS and VAE, particularly in the United States where medicine and health insurance are large for-profit enterprises. As others have argued, one need not reject PAS and VAE as unethical in order to reject the legalization of these practices. $^{\text {xiv }}$

Returning to the Nazi! accusation, one further reason becomes evident for ridding ourselves of that charge in our discussions of PAS and VAE. 
Facing that accusation we may find ourselves confidently saying "that would never happen here." In this way the Nazi! accusation and the relatively easy refutation of it console us, as if our greatest concern were that we not become neo-Nazis. Our own specific temptations, however, require greater attention, for they are much more ordinarily humane and human.

\section{NOTES}

${ }^{\mathrm{i}}$ For extended considerations of the Nazi "euthanasia” program, see M. Burleigh, Death and Deliverance: "Euthanasia” in Germany 1900-1945, Cambridge:Cambridge University Press, 1994 and H. Friedlander, The Origins of Nazi Genocide: From Euthanasia to the Final Solution, Chapel Hill:The University of North Carolina Press, 1995.

${ }^{\mathrm{ii}}$ For a recent instance of the Nazi! accusation in the debate concerning euthanasia, see P. Singer, "On Being Silenced in Germany”, New York Review of Books, 1991, 38, pp. 34ff.; see also M. Burleigh, Death and Deliverance, pp. 291-298.

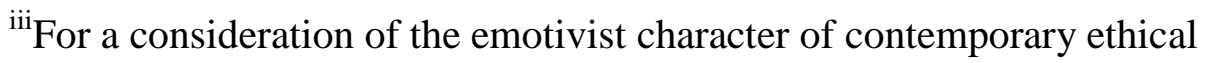
discourse, see A. MacIntyre, After Virtue, Notre Dame:University of Notre Dame Press, 1984, pp. 6-35.

${ }^{\text {iv } H . ~ F r i e d l a n d e r, ~ T h e ~ O r i g i n s ~ o f ~ N a z i ~ G e n o c i d e, ~ p . ~ 81 ; ~ f o r ~ a ~ c o n s i d e r a t i o n ~ o f ~}$ the non-Nazi German precedents to the Nazi "euthanasia" program, see M. Burleigh, Death and Deliverance, pp. 11-90. 
${ }^{\mathrm{v}}$ See, for example, L. Dawidowicz, "Biomedical Ethics and the Shadow of Nazism”, Hastings Center Report, Aug., 1976, Vol. 6, No. 4, pp. 1-19.

${ }^{\mathrm{vi}}$ Of course, one might judge a life not worth living in other than physical terms; for example, because of the pangs of dispriz'd love or the weariness of bearing fardles. This raises questions concerning whether the criteria for PAS and VAE could be limited solely to medical and somatic conditions such as an imminently terminal illness or a progressively debilitating disease.

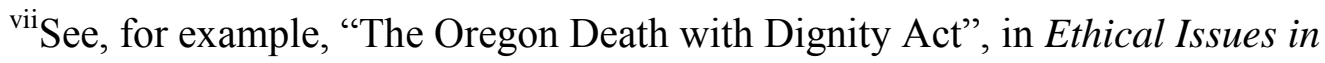
Death and Dying, T. Beauchamp and R. Veatch, eds., New Jersey:Prentice Hall, 1996, pp. 199-206; T. Quill, C. Cassel, and D. Meier "Care of the Hopelessly Ill: Potential Clinical Criteria for Physician Assisted Suicide", New England Journal of Medicine, 1992;327:1380-84; for a consideration of the California ballot measure that sought to legalize PAS and VAE, see L. Kass, "Death on the California Ballot: Giving Healers the Sanction to Kill", American Enterprise, Sept.-Oct., 1992, Vol. 3, No. 5, pp. 44-51.

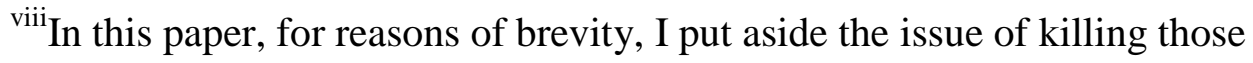
who cannot themselves desire or express a desire to be killed, for example, infants and children. Considerations concerning health-care decisions for the non-competent suggest that, if legalized, VAE would eventually develop to include killing some individuals who themselves have not expressed a desire to be killed.

${ }^{\mathrm{ix}}$ See M. Burleigh, Death and Deliverance, pp. 93-96. 
${ }^{\mathrm{x}}$ See H. Friedlander, The Origins of Nazi Genocide, pp. 171-173.

${ }^{\mathrm{xi}}$ For a consideration of the actual number killed in the Nazi "euthanasia" program, see H. Friedlander, p. 109.

xii J. Feinberg, "Whose Life is it Anyway?", in Harm to Self, New York:Oxford University Press, 1986, pp. 351-362.

${ }^{x i i i}$ For an example of this romanticizing of PAS, see T. Quill's description of assisting his patient Diane that concludes with his asking if "I will see Diane again, on the shore of Lake Geneva at sunset, with dragons swimming on the horizon", T. Quill, "Death and Dignity: A Case of Individualized Decision Making”, New England Journal of Medicine, 1991;324:691-94.

${ }^{\text {xiv }}$ A. M. Capron, "Should Some Morally Acceptable Actions of Killing and Letting Die be Legally Prohibited and Punished?", in Intending Death, T. Beauchamp, ed., New Jersey:Prentice Hall, 1996, pp. 188-198. 